\title{
The Moving Line Between State Benevolence and Control: Municipal Indigent Programmes in South Africa
}

Journal of Asian and African Studies 2018, Vol. 53(2) 169-186 (C) The Author(s) 2016 Reprints and permissions: sagepub.co.uk/journalsPermissions.nav DOI: $10.1177 / 0021909616667522$ journals.sagepub.com/home/jas

@SAGE

\section{Greg Ruiters}

School of Government, University of the Western Cape, South Africa

\begin{abstract}
'Municipal indigents' are a category of poor citizens who qualify to receive certain municipal services for free in South Africa. Having registered as municipal indigents, the poor not only gain access to free basic services but also embark upon a voyage into a bureaucratic underworld where policies are changed and eligibility criteria and sanctions are unevenly applied. Various preconditions and limits on services, as well as social surveillance of indigent households, has turned indigency programmes into a 'regime'. The policy has swung from hard cost recovery (mass disconnections) during the period 1994-2000 to 'free' basic services and, more recently, to social-shaming and criminalisation. This paper provides a thematic account of recent municipal indigent processes in order to explore the 'moving boundary' between benevolence and control regarding this crucial citizen-state interface. Based on recent interviews with government officials, a review of relevant government documents, and describing the administrative complexities, the paper reveals aspects of what the poor confront in day-to-day experiences of the state. It is argued that there are lessons for all municipalities seeking a more sustainable and democratic path to citizenship rather than an ongoing low-level war with poor citizens.
\end{abstract}

\section{Keywords}

Free basic services, indigents, local government, policy analysis, South Africa, surveillance

\section{Introduction}

In March 2012, Ratanda - a black township in the Lesedi Municipality, south east of Johannesburg - experienced an exceptionally violent uprising lasting three days. Eight councillors' houses and municipal buildings, including the library, were attacked. The protestors were assuaged only after the Minister of Police and the Minister of Co-operative Governance and Traditional Affairs arrived to address the huge crowd in the local stadium (Independent Online, 23 March 2012).

\section{Corresponding author:}

Greg Ruiters, Professor, Co-director of Municipal Services Project, School of Government, University of the Western Cape, Bellville, 7535, South Africa.

Email: gregruiters59@gmail.com 
The protestors grievances included: arbitrary electricity cuts, inaccurate billing to households, a $16 \%$ electricity price increase, legitimate indigents disconnected and long delays in approving indigent applications. In 2012, there were only 1500 registered indigents - too few for a sizeable poor township. According to the municipality, 'there were genuine issues' (in the community). The indigent register and database had not been updated in 2011 (Interview with a Senior Official, Lesedi Municipality, 5 August 2015).

The municipality argued that although they were 'in the wrong in 2012, matters had improved' (Interview with Senior Official Lesedi Municipality, 5 August 2015). Following the 2012 uprisings, councillors in this municipality no longer approve indigent applications, because this has added to delays (Interview with Senior Official Lesedi Municipality, 5 August 2015). Rather, the Finance department was put in charge of indigents. 'We now just use ID numbers; we have mass registration drives and indigent road shows' (Interview with Senior Official Lesedi Municipality, 5 August 2015).

Protestors, it seemed, had won a small victory. By June 2015, the Mayor of Lesedi municipality proudly announced that, 'our registered indigents have surpassed the 4000 mark. We also expect this number to increase as part of our objective to ensuring that all our indigents in within our municipality do receive free basic services' (Lesedi Local Municipality, 18 June 2015). At the time, the municipality saw major 'challenges' in implementing the indigent policy of the municipality, ranging from 'lack of awareness to compliance'. However, in 2015, electricity 'theft' was still a big problem. In Lesedi the problem of illegal electricity connections was regarded by local government as being severe. The municipality claims it is able to monitor household electricity purchases and when households do not buy electricity for several weeks or more the municipality sees this as an indicator of an illegal connection (about 1200 of 30,000 households were 'stealing' electricity). The municipality is able to identify areas where electricity re-appropriation is occurring following which, as a first step, they remove the meter box and then, as a second measure, they remove cables (Interview with Finance Manager, 22 July 2015). Several other municipal officials (Interviews, August 2015) complained that residents in townships in particular are trapped in a 'culture' of nonpayment - a residue of the rent boycott protests in the 1980s.

The Ratanda case, however, illustrates many key debates, movements and ambivalences in both the national indigent policy framework and the local implementation process. Using interviews with municipal officials, ${ }^{1}$ this paper is based on the author's interest in how poor residents of black townships in South Africa experience municipal bureaucracies and municipal services. An attempt is made to present an understanding of the reciprocal dynamics at the citizen-state interface. It is shown that 'indigency' - a discrete category applied by municipalities - is how the South African local state, in what might be regarded as the most unequal country in the world, 'deals' with the very large numbers of poor, almost all of whom are black. The focus of the paper is on the following themes in municipal indigent policies:

(1) The oscillations in the application processes and agency or department responsible for managing indigent lists and ways of verifying indigency;

(2) Changing targeting mechanisms (indigent lists, income, property valuation, universal);

(3) The quantum of services and range of benefits;

(4) The indigency exit programme; and

(5) Citizen morality and punitive measures for false information and non-payment.

I then consider general political issues in indigency regimes: I do not examine popular responses in any detail but focus on the local state machinery and indigent policies. 
If we regard policy (such as the indigence policy) as a 'field of power' in which governments or parties assert hegemony (Clarke, 2004), then it becomes important to grasp the details of such policy, its techniques, mixtures of coercion and consent and their changes. Hegemony includes the power to name a problem, to set an agenda and rules for policy and the exercise of material power. This 'field of power' is one in which government hegemony has to be constantly reinforced. Much of the existing critical work on local policy tends to expose the policy-implementation gap (Tissington, 2008), or dismiss indigent policies and state welfare as tokenistic (Bond, 2014), or reduce it to a single state logic (Naidoo, 2006, 2010). I argue that in contemporary South Africa the contradictory impulses and oscillations in South African social policy (helping and containing the poor) mean that it is necessary to go beyond simply dismissing policy as anti-poor or inconsequential; see also Titmuss (Abel-Smith, 2008), who insisted on detailed studies of bureaucratic processes. Oscillations and fine tuning of policy are partly a response to the growing list of indigents and adaptive struggles of the poor for survival. It is important to study the moving boundaries between benevolence and control, between coercion and consent, in the administration of 'indigents', because millions of black, poor people are affected.

\section{From coercion to paternalism: free services and indigent policies for the period 1994-2006}

The term 'indigent' has gained currency in South Africa when, after 2001, municipalities started to introduce free basic services. At least three and a half million mainly black poor households (25\% of the total population) in South Africa qualified as indigent in 2014, according to the state (RSA, 2015). Together with government schemes to assist the 'most vulnerable' - social grants, free Reconstruction and Development Programme (RDP) housing, no fee schools and other support programmes - indigent social packages (free basic water and debt write-offs) have become the ANC's 'social wage' for poor people. Child support grants grew from a mere 150,000 beneficiaries in 2000 to ten million recipients in 2011 (RSA, 2014). Grants do make a significant difference, although means tested support continues to stigmatise recipients (Wright et al, 2014). However, it has also been argued that the state welfare system is a form of encadrement/patronage used by the ANC to ensure that it maintains the electoral loyalty of the black poor (Berman, 2016).

It is important to note that from 1994 to 2001 South Africa had no free municipal services for the poor and a coercive approach was used (what some might call 'roll-back' neoliberalism). All services had to be paid for by all households (rich and poor ). Non-payment could result in total cut-offs of services; and tariffs were set to allow municipalities to recover the full operating costs of supplying water (McDonald 2002). As Atkinson argued,

In the past, most municipalities have used a coercive approach to securing payment. This involves cutting off water or electricity supplies ... However; there are many implementation problems with regard to coercive approaches: Cutting off water often does not always lead to payment of arrears. Defaulters may simply steal water, or install illegal connections. Many Councillors are reluctant to take strong political measures. (Atkinson, 2002: 39)

In addition to the coercive aspects mentioned by Atkinson (2002), a cholera epidemic in KwaZuluNatal in 2000-2001 resulted in 265 deaths (Hemson et al, 2006). The problem, as the government explained,

...is that when we try to implement cost recovery, many of the poor cannot pay. The consequence, when they are then excluded from the taps, has been seen with the cholera outbreak in KwaZulu-Natal. (Kasrils, 2000) 
In 2000, under Kasrils' leadership, a rethink led to a nation-wide free basic water policy for the poor, to be funded by national government through equitable share allocations. As Kasrils recalled, 'If I have to reflect back then one of the key milestones was the development and implementation of the Free Basic Water policy in 2000' (DWA, 2004: 5). As Mike Muller, the director general who had defended full cost recovery, admitted,

We have had to confront the fact that in a very unequal society like South Africa, a policy of cost recovery, which makes perfect sense in a more equitable society, would exclude the poor from access to that basic commodity, to which they have a right. (New York Times, Water Tap often shut for the poor, 29 May 2003)

This was thus a major shift in the policy of universal full cost recovery, and social movements saw it as a victory for the poor (Cosatu, 2006; Bond 2008). The government defined 'basic water' as

the infrastructure necessary to supply 25 litres of portable water per person per day supplied within 200 metres of a household and with a minimum flow of 10 litres per minute (in the case of communal water points) or 6000 litres of portable water supplied per formal connection per month (in the case of yard or house connections). (RSA, 2006: 20)

The main advisors to the Department of Water Affairs and Forestry (DWAF) stressed that free basic water (FBW) was integral to cost recovery and not a policy reversal:

The availability of options, which restrict the flow to consumers, is an important attribute of a good local free basic water policy. It allows people who cannot afford to pay more, to get only a basic supply (poverty relief level). Under a free basic water policy, it is essential that all unrestricted supplies are metered. (Palmer Development Group, 2001: 14)

Among water experts and bureaucrats, FBW policy was both a humanitarian act and a managerial device. As Muller argued, it is 'an innovative approach that will enable us to separate the can't pays from the won't pays' (Muller 2001a: 14). It is not difficult to extricate the moral coding in this essentially new public management discourse (Clarke and Newman, 1997). This reinforces the idea, well-known in policy literature, that policies have hidden agendas and implicit value systems (Weiss 1998: 53; Walker 1993). Muller (2001a: 38), a senior state official, argued that 'the key issue is that the programme is designed and implemented as part of a larger process of building local government' and identifying 'free riders'. Naidoo (2006: 8) has suggested that the 'real aim' of indigent services is to trap the poor into 'binding agreements to pay for their services'. However, there seem to be a number of logics behind free basic services and the indigency system - such as dividing the very poor and the poor and the working class.

While the free basic water policy was heresy in some water circles, its implementation is already helping to promote accountability and good financial management in local government. The distinction between the 'can't pays' and the 'won't pays' is clarified and 'free-riders' with higher than basic levels of service more easily identified. (Muller, 2001b)

The Department of Finance, led by Trevor Manuel who presided over an increasingly unequal South Africa, suggested that, 'to make it (FBW) work, only the really proven poor should get these while anyone else should be forced to pay even at higher tariffs' (Department of Finance, 2001: 132). In some ways, the less poor would find themselves under more pressure to pay more and pay regularly. The poor, on the other hand, while not paying for services at all would have to be restricted to a 'basic lifestyle'. 
Table I. Overview of variations in municipal indigence schemes.

\begin{tabular}{|c|c|c|c|c|}
\hline Municipality & $\begin{array}{l}\text { Department } \\
\text { responsible } \\
\text { for indigent } \\
\text { registration }\end{array}$ & $\begin{array}{l}\text { Criteria for } \\
\text { registration }\end{array}$ & Benefits of registration & $\begin{array}{l}\text { Periodic review } \\
\text { of beneficiaries }\end{array}$ \\
\hline Cape Town & Finance & $\begin{array}{l}\text { Household } \\
\text { Income and } \\
\text { property }\end{array}$ & $\begin{array}{l}\text { - No property rates } \\
\text { - Free } 50 \mathrm{~kW} \text { of electricity } \\
\text { and R30 subsidy } \\
\text { - Free } 6000 \text { litres of water } \\
\text { per month }\end{array}$ & 12 months \\
\hline Ekurhuleni & Finance & $\begin{array}{l}\text { Household } \\
\text { income and } \\
\text { property }\end{array}$ & $\begin{array}{l}\text { - } 9000 \text { litres of free water } \\
\text { - } 100 \mathrm{kWh} \text { free electricity } \\
\text { - } \quad \text { No property rates } \\
\text { - } \text { Free refuse removal }\end{array}$ & 18 months \\
\hline $\begin{array}{l}\text { Nelson } \\
\text { Mandela } \\
\text { Bay }\end{array}$ & Treasury & $\begin{array}{l}\text { Household } \\
\text { income }\end{array}$ & $\begin{array}{l}\text { - No property rates } \\
\text { - } 8000 \text { litres of free water } \\
\text { per month } \\
\text { - } 75 \mathrm{kWh} \text { of fee electricity }\end{array}$ & 12 months \\
\hline eThekwini & $\begin{array}{l}\text { No indigent } \\
\text { registration, uses } \\
\text { of valuation roll }\end{array}$ & Property Value & $\begin{array}{l}\text { - No property rates } \\
\text { - Free } 65 \mathrm{kWh} \text { of electricity } \\
\text { - } 300 \text { litres per day free } \\
\text { water }\end{array}$ & None \\
\hline Johannesburg & $\begin{array}{l}\text { Community } \\
\text { Development }\end{array}$ & Income/capital & $\begin{array}{l}\text { - Free services according } \\
\text { to poverty index }\end{array}$ & 6 months \\
\hline Tshwane & $\begin{array}{l}\text { Health and Social } \\
\text { Development }\end{array}$ & $\begin{array}{l}\text { Household } \\
\text { income }\end{array}$ & $\begin{array}{l}\text { - } \quad \text { No property rates } \\
\text { - Free } 100 \mathrm{kWh} \text { electricity } \\
\text { - Free } 12,000 \text { litres of } \\
\text { water per month }\end{array}$ & 24 months \\
\hline
\end{tabular}

Source: adapted from Pillay (2010).

\section{Setting standards for indigent services}

In an attempt to provide some standards, central government developed an Indigent Policy Framework in 2005 (RSA, 2006). The government was at pains to stress that free services 'must be accessible for all poor residents, implying that those in unregulated settlements (and those living in back yards) must be brought into the municipal system so that residents are not excluded from indigent support' (RSA, 2006: 8). Most municipalities, however, only provided free services to municipal account holders, thereby excluding backyarders.

National guidelines also prescribe a basic package: 'it is recognised that resource constraints prevent many municipalities from delivering a fuller range of services free to the indigent. Therefore, the definition of the essential services package, to be provided to all, is kept relatively narrow'. (RSA, 2005)

Fixing the basic water supply at 6000 litres per month (and delivering this amount through the communal tap) is often not realistic given the needs of large poor households and the densely populated townships where water requirements are around 15,000 litres per month - significantly higher than 6000 per month. As Table 1 shows, levels of services and amounts vary between municipalities. Some offer 6000 litres, others up to 10,000 litres.

\section{Variations in targeting methods}

The government guideline document indicates the different methods for targeting the poor, and the advantages and disadvantages of each method (RSA, 2005: 23-24). By 2014, almost 70\% of 


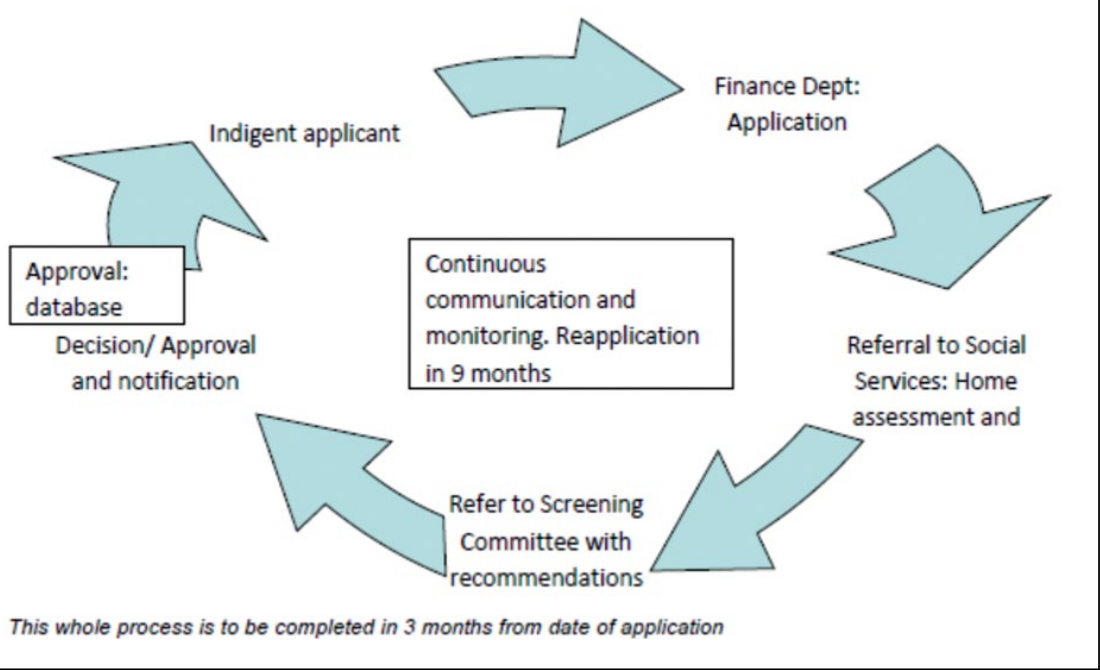

Figure I. Procedures and processes for implementation.

Source: Midvaal Municipality (2014).

municipalities used household income thresholds and fixed these at R2701 a month (RSA, 2015). Cape Town offers the FBS to all households and so it does not have to verify indigent incomes. It offers extra benefits to those who register and insists that indebted households must use flow limiters so that they can be held to the monthly free quota. Table 1 shows how different municipalities have implemented the national policy.

In larger municipalities (eight metros) most beneficiaries will be automatic indigents (i.e., they do not need to apply to be registered as indigent); but in the large majority of medium to small municipalities the poor have to apply in person at local offices. Given the detailed information required for eligibility (age, income, size of household, etc.), surveillance and micro-controls thus become a source of conflict between citizens and the state.

\section{The application process and 'continuous' surveillance of the poor}

The application process (which department to apply to, the role of ward councillors in vetting applications, waiting time and re-verification) differs for each municipality. Many municipalities have repeatedly changed their criteria, procedures and rules for indigency. Figure 1 and Table 1 show that in Ekurhuleni and Midvaal both the finance and social development departments are involved.

The process is typically quite elaborate and labour-intensive: once the application is received, the state carries out a house visit, to assess eligibility (often the entire household's income must be declared), and if there are indicators of material wealth such as a television or Internet access, then the application might be declined. In the financially stressed Metsi Maholo Municipality, a senior municipal official noted, 'We employ fieldworkers to do checks' (Interview, 17 June 2015). Lesedi's new policy (2015, clause 11.1.17) states that

...the assessments of indigent's applicant's include a lifestyle audit and ownership of luxurious items e.g. Motor car, DSTV decoders etc [sic]. Where tampering is discovered, all benefits will immediately be suspended. A fine according to the Credit Control and Tariff Policy will be imposed. The service will be 
terminated and will only be re-installed on the payment of the full amount of the reconnection fee and fine (Lesedi Local Municipality, 2015)

As the newspaper Business Day (8 September 2011) noted,

Where SARS does not believe that a taxpayer has made full disclosure of income in a return, he or she could be subject to a lifestyle audit. Since the Congress of South African Trade Unions' general secretary Zwelinzima Vavi coined the term two years ago, it has been associated with politicians, such as Julius Malema, whom the Hawks are investigating after allegations of tender fraud.(Business Day, 2011)

It is significant that the Lesedi Municipality extends the term lifestyle audit to the poor. The applicant has to update their status annually or, in some cases, every six months. In other words, monitoring (surveillance) by the state is 'continuous', as is stated explicitly in the Midvaal process (see centre-box in Figure 1, which shows the application cycle).

The Democratic Alliance (DA)-run Midvaal Municipality has a stringent process and stringent criteria for indigency, but admits the 'whole process is beset with difficulties' (Midvaal Municipality, 2014: 666). ${ }^{2}$ Ekurhuleni Municipality (2014) noted that, 'Indigent relief will NOT be granted where the applicant,

(a) Receives significant benefits or regular monetary income that is above the indigent qualification threshold;

(b) Is not registered as consumer of services in the records of Council;

(c) Rent/s or subleases his property or part thereof to any third party during the duration of the grant period; or

(d) Tampers or illegally connects or reconnects services prior to this application, until such time as the total costs, penalties, other fees, illegal consumption and any applicable tariffs and rates due to the Council have been paid in full.

In Ekurhuleni, to be registered according to its Indigent Support Policy,

...the applying citizen must present his/her Identity Document with copy of monthly account statement and/or prepaid meter token along with SAPS (Police services) certificate affidavit of names and identity number of individuals residing on property at the point of application. The onus is on the recipient of relief to inform the Council of any change in his/her status or personal household circumstances. ...Criminal charges may be brought against such person/s. (Ekurhuleni, 2014: 10)

Kenny Tsotetsi, a community activist linked to recent protests in Ratanda, argued that, 'the municipality audits people's homes looking for brandy, dstv decoders, or furniture accounts to disqualify indigents' (Interview, 27 July 2015). Lesedi's Head of Community Services noted that a 'teacher living with a pensioner will get free services. We scrutinised the indigent applications and found many irregularities. The culture of non-payment is a problem' (Interview 24 July 2015).

Dlamini noted that,

...in Mogale City the registration of indigent applications are handled at the municipality's headquarters in Krugersdorp. For the poorest of the poor, the central office in Krugersdorp may require transport, which is a cost. However, activists argue that the indigent management should be decentralised. There are community structures such as ward committees, community liaison officers and community development workers which can be harnessed to handle registrations. (Dlamini, 2011: 72-73) 
A final example: in Mbombela, the ward councillor has to 'recommend' the applicant and, importantly, the final list is made public (Mbombela, ND) thus allowing for public shaming of alleged fraudsters and neighbours, designed to expose undeserving indigents.

According to Seri's review of indigent policies,

...of the indigent policies examined, 32 policies encouraged residents to examine the list of prospective indigents and verify that people on the list are indeed indigent. The idea is that the indigent register should be made public for comments by members of the public, who are entitled to make objections to the register in respect of any other person's qualification as indigent. (Seri, 2013: 63)

A local community development worker in Lesedi noted that,

the indigent policy is not working ... it takes a year to get registered as an indigent. If the owner of the house has no papers they have to go to the high court to prove ownership to apply for indigent status. (Interview, 27 July 2015)

Free services notwithstanding, elderly residents of Lesedi receive bills of R1300 a month (Interview, 27 July 2015). Clearly, the effective administration of indigency is a major burden for municipalities.

In summary, municipalities have made the application process as unpalatable and timeconsuming as possible for residents. The state appropriates time. It is likely that many indigents will also be child support grantees who also queue for long periods to get benefits. Researchers investigating the child support grant (CSG) reported that, for example, 'The process of applying for CSG was described by many as being detrimental to dignity, as was the opprobrium often associated with their status as CSG recipients' (Wright et al., 2014).

The sheer fact of having to queue for long periods is presented as something that erodes dignity, as it conveys the impression to the CSG applicants that SASSA does not consider them or their time to be important and as such this is detrimental to women's sense of worthiness. Queuing was also described as stigmatising. (Wright et al., 2014)

\section{The number of registered, active indigents}

Although there may be millions of poor households needing free services, many do not register and many are disqualified technically: for example, backyard shacks or illegal shacks (nonaccount holders) are excluded. The government's view is that the 'most vulnerable societal groupings (women, child-headed households, and the unemployed)' do not register for 'fear of attracting adverse official attention and many are also not aware of these concessions'.

In Tshwane Municipality, for example, in 2008 the goal was to get 90,000 indigent households to register. The council had only registered about 50,000 indigent households (SA News 28 January 2009). In fact, in most municipalities, the number of registered indigents is admitted to be grossly under-representative of those who actually qualify (Tissington, 2008).

The City of Johannesburg increased the number of indigent households with free basic electricity from a mere 12,600 in 2013 to 288,000 in 2014 (see Table 2). The indigency programme is a massive programme even if uneven and erratic as shown in Table 2. In 2014, the indigent numbers increased by 140,000 , or $4.2 \%$, from 2013, thanks to awareness drives by councils about their indigent policies (RSA, 2015). The non-financial census of municipalities, 2014 noted that municipalities had registered more indigent households to benefit from free basic services, but were struggling to deliver these services to all those who qualified (RSA, 2015). 


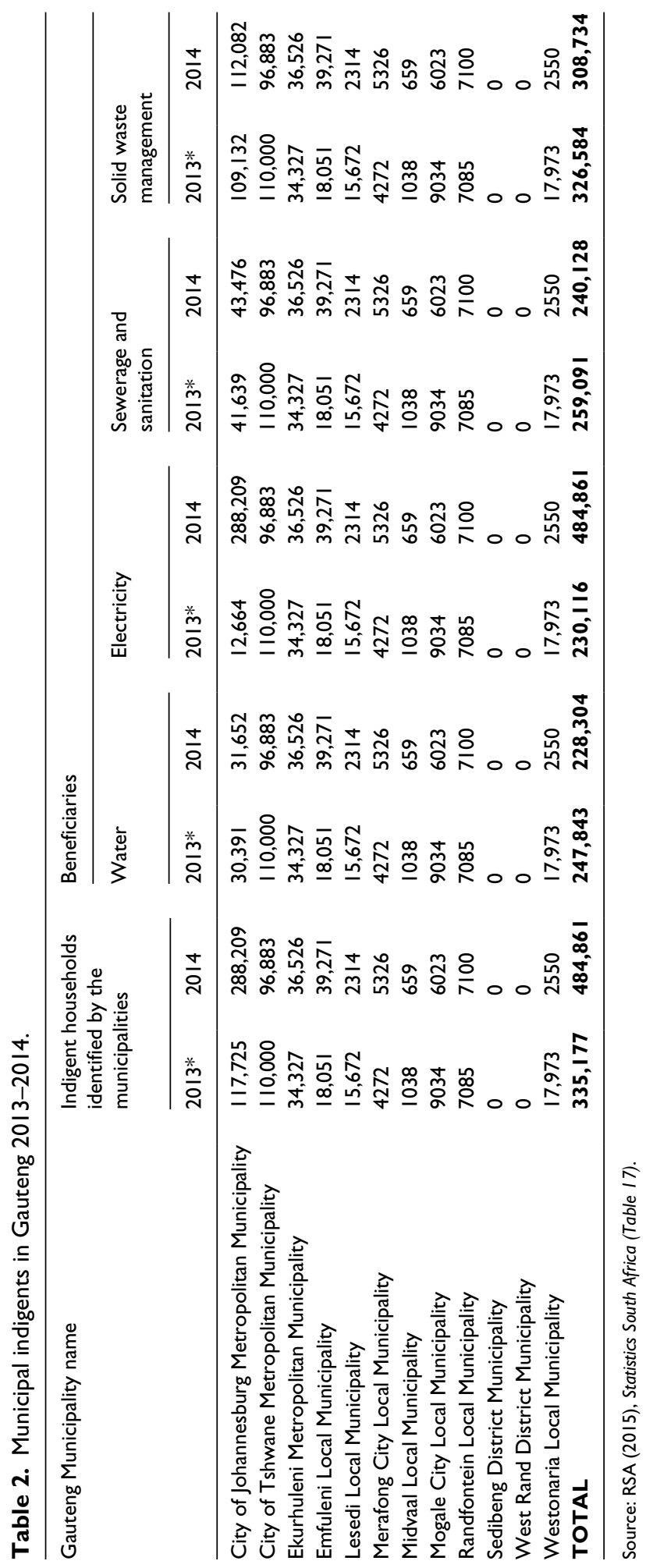




\section{Exit strategies: 'graduating out' of poverty}

While stressing inclusion, the state wants households whose circumstances have improved to be taken off indigent registers. In the Draft Indigency Guidelines (RSA, 2005), the government had already noted that, 'Municipalities need to start planning realistic exit strategies for their indigent populations to exit from the indigent registers and subsidies' (RSA, 2005). Municipalities impose onerous pre-conditions, such as regular re-registration, on households, thus keeping large numbers of poor households off the list and ensuring their exit (see Table 1). Ekurhuleni Municipality, using Orwellian language, similar to the apartheid regime, insists that it wants 'to ensure the implementation of an exit strategy to support the increased mobility of the poor from the indigent register' (Ekurhuleni 2014).

In Tshwane, the indigent 'exit strategy' for Tshwane (see Pillay, 2010) 'is a mechanism for tracking households deemed indigent in order to determine when they should be graduated off (sic) of the indigent register'. Tshwane like other municipalities 'is concerned about the cost of free basic services increasing in future. All of this constitutes a strong rationale for having an effective indigent exit strategy' (Pillay, 2010). However, so-called 'exit strategies for identified indigents are not well planned or clearly outlined' (Seri, 2013: 46). Exit speaks to the ANC fearing dependency among the poor. In 2004, in his State of the Nation speech, President Mbeki stressed that,

We should not cultivate a culture of dehumanizing dependency in these masses through increasing welfare. ... The objective is that we should increase the number of people in society who depend for their livelihood, not on social grants, but on normal participation in the economy.

\section{State morality after $20 \mathrm{II}$ : between the genuine, the corrupt and the feckless}

Indigent lists/registers are a major political-moral interface with the officially defined poor (those with less than R2500 per month in household income). Poverty is only recognised by the state when certain rigid criteria are met. Second, once categorised and registered as indigent, a variety of other remedial programmes can be linked to this status (e.g. unemployed indigents can be put onto municipal employment databases and provided with jobs in the expanded public works programmes). Third, the poor are deemed to be of this status partly because they lack a 'work-seeking' culture and fail to prioritise spending (Clarke and Newman, 1997; Pithouse, 2008). In addition, the surveillance of the indigents can be increased under the guise reducing fraud, through social worker home visits. In some municipalities such as Cape Town, for example, an explicit link is made between the generosity of the ratepayer and the ability of the municipality to provide free services for the poor. The moving boundary between helping and controlling in South Africa has created new black subjects of local administration sometimes seen as deserving poor but also as abject. Abject racial subjects such as 'indigents' are positioned in official and policy discourses as potentially criminal and pathological. Worried about poor state finances, municipal bureaucrats have openly stigmatised the black poor as dependent 'lazy communities' having a 'culture of non-payment', with an implicit comparison to whites who are the norm of civic mindedness (Ruiters, 2007; Makhubu, 2013).

A recent trend however is for municipalities to 'update their policies' to enhance punitive measures against 'fraudsters'. With huge unpaid municipal debts to Eskom, the national electricity provider, Minister Gordhan identified two key issues in indigent processes. First, municipal indigent registers needed to be 'cleaned up' since,

...we find that indigent registers, sometimes, have the names of public sector officials, business people and professionals so that they now get exempt from paying for municipal services. That then deprives the municipality of very urgently needed revenue on their side. (Independent Online 11 June 2015) 
Second, Gordhan noted, 'there is a non-payment culture among communities that can actually afford to pay' (Independent Online, 11 June 2015).

This social-moral regime was dramatically intensified by President Zuma's statements in 2015 (Independent Online 25 March 2015), when he remarked that he 'wished he were a dictator' so that he could reverse his own government's policy on providing grants and public services. 'People don't want to work because they are free'. (Independent Online, 25 March 2015) The ANC has stated in a somewhat more diplomatic manner that the South African state's social policy needs to be more targeted in order to reach the truly poor while the emphasis must be on 'developmental' programmes that enable the poor to live a 'normal life'. Developmental local government was to be a key pillar of policy.

The DA offers a paternalistic slant. The City (City of Cape Town, 2014) noted that the city is 'accountable for their spending of ratepayers' money'.

We already provide generous free basic services in Cape Town. And the only reason we can do this is because we have a middle class who can subsidise the poor. In the three years since the DA came to power in Cape Town, we have doubled free basic services by taxing the rich and giving to the poor.... Of course we cannot continue raising rates. But fortunately most people from the middle class realise that we have to give services to the poor. (Stephanie Nieuwoudt, interview with the leader of the Democratic Alliance, 18 May 2009, emphasis added $)^{3}$

Since the financial crisis of 2008, policy has taken a more conservative, revanchist attitude. The government's campaign against illegal electricity connections appeals to honest residents to report 'thieves' (called izinyoka, snakes, in Zulu) (Sowetan, 19 April 2012) ${ }^{4}$. Johannesburg Water's managing director complained that many Soweto residents pleaded poverty when payment for water was due.

When you drive around Soweto, there is a mixture of people who are indigent and those who plead indigence but are not. You can't say you're indigent and yet you run DStv and you watch pay TV. There's also this culture that says water is free. (Times Live, 20 May 2015)

Pro-poor social policies thus always have normative content, and they seek to change or direct the behaviour of subject populations. The moral component of state social policy or welfare includes an image of how things ought to be, beliefs, ideologies about the state, society and the good citizen. These processes are mediated locally and are revealed in the ambivalent ways the 'target populations' view the state's efforts (see Pithouse, 2008).

\section{The wider issues and policy debate}

Municipal officials often blame their problems on the central state's policies of providing free RDP housing for the poor who cannot afford the services, then run up debts and become dependents on municipalities (Interview with Finance Manager of Lesedi Municipality, 27 July 2015). These officials also blame the poor for feckless conduct (Pointer, 2015). Pressures have increased on municipalities from all sides. In 2015, the central state threatened to withhold equitable share payments to 70 municipalities. The South African Local Government Association (Salga), representing all municipalities, has suggested that metros should no longer provide free basic water to all.

It costs the five biggest municipalities R3.7 billion annually to provide free water, even to those who can pay. Ekurhuleni could realise annual savings of R1.8 billion by providing free basic water only to the 37,000 residents registered as indigents. Cape Town might save more than $\mathrm{R} 380 \mathrm{~m}$. 
Moreover, stopping the 6000 litres per month of free water to millions who are marginally above the poverty line (the missing middle) could lead to a significant increase in household municipal bills.

Municipal leaders are concerned about unemployment; and job losses contributed to a shrinking municipal tax base, resulting in lower payment levels for municipal services. Protests have increased dramatically and the state has continued to attempt to achieve a balance between maintaining political legitimacy and squeezing the poor and middle class. By June 2014, municipal consumer debt stood at R94 billion and households were R58 billion in arrears (Sowetan, 14 March 2015). The City of Johannesburg is owed the largest amount (R17.4 billion), followed by Ekurhuleni (R10.7 billion) and Tshwane (R6.6 billion).

Municipal bureaucrats claim that households typically fail to budget properly, to prioritize municipal payments or know their usage. However, matters are more complex. McDonald (2002) showed that South Africa consumers do care about their water usage and bills. Szabó also found that,

The issue is also not that consumers simply do not care about water. In our sample, close to $40 \%$ of respondents stated recently talking to neighbours or friends about water use. Instead, the primary issue appears to be that consumers have trouble understanding the information that is presented to them. For example, over $80 \%$ of consumers were unable to tell their consumption from their water bill. In general, households exhibited very little familiarity with the meaning of the numbers on the meter and the units in which their water consumption was being measured. (Szabó, 2015)

Municipal governance problems in South Africa derive in part from the larger political economy, which produced local government as a third sphere of government, but largely self-financed through selling services and collecting property rates (Atkinson, 2002; McDonald and Ruiters 2005). Unlike provinces, municipalities are obliged to raise their own revenue and recover costs and they are permitted to privatise services. The Municipal Systems Act (1999) obliges cost recovery; and section 104 of the Act legalizes (i) the termination or restriction of municipal services; and (ii) the seizure of property.

Indigency programmes have been attacked from all sides of the political spectrum: left and right. The policy debate about the indigent poor may be considered in at least four ways. First, the Centre for Development and Enterprise, together with the World Bank and the private sector, took a hardline neoliberal position, criticising the principle of free basic services programmes (and indigent relief programmes) as populism and patronage that undermines the 'payment ethic' (also see The Economist, 19 July 2003). Atkinson argued that giving free services takes away the little self-respect the poor have.

Ironically, many of the most faithful customers (in terms of payment for services) were residents within the 'indigent bracket' - notably, elderly pensioners, who are prepared to pay for services, due to their own self-respect or respect for public institutions. (Atkinson, 2002)

John Kane Berman took this further by suggesting that indigents are part of an ANC patronage machine.

Clients of official (ANC) patronage are public servants, and urban households who often pay nothing for water and electricity. Yet others are more than nine million children in no-fee schools. They may not vote, but their parents do. Recipients of social grants - nearly 17 million of them - are beneficiaries of the state. (Berman, 2016) 
Dawson (2014) made a related point that 'corruption and favouritism' are the prominent complaints in local protest and that 'patronage and collective action work together'. Furthermore, Dawson suggested that,

...the close relationship between the ANC and the state at the local level gives rise to particular patronclient relations between low-income residents, the ANC, and the state. As a result, the state is not understood as a bureaucratic dispenser of public goods on the basis of rights but as a relational system of reciprocal dependence and obligation. (Dawson, 2014: 518)

Indigent lists, by extension, might form part of these local patronage systems. As Kenny Tsotsetsi, a community leader, stated it, 'indigency is used by local government as political patronage' (Interview with Kenny Tsotsetsi, 27 July 2015).

Second, differing in approach from the above authors and adopting a social rights perspective, Devereux argued that,

South Africa's social protection system is exceptional not only because of the extensive coverage, relative generosity and efficient delivery, but because these grants are underpinned by political commitment and legislated rights. Uniquely in Africa, the social protection agenda has been government-led, driven by domestic civil society rather than external donors, and enforced by a justiciable 'social contract' established in the constitution. (Devereux, 2011)

A third view suggests that 'pro-poor' policies also make sound economic sense. They would paradoxically 'enhance sustainability' because the 'adoption of the free basic water policy has not negated this (user-pays) principle'. On the contrary, the government argued that free basic water policy 'strengthens the payment principle in that it clearly requires additional consumption to be paid for while allowing for free basic access by the poor necessary to sustain life - a constitutional right'. The state could chase the 'non-poor' households; state bureaucrats also termed such households 'the won't pays' (Muller 2001a). Here, a commercial rather than patronage logic is at play. As Atkinson noted,

...payments levels have always been low, at least partly because of high levels of poverty ... policy, related to subsidizing indigent people to afford monthly basic services, should address this issue to a large extent. A proper credit control depends on the primary work of determining who the indigents are, so that credit control efforts can be targeted at non-indigents who are in arrears. (Atkinson, 2002: 39)

A fourth view - a left-wing argument (see Bond, 2014) is that South Africa's social policies are tokenistic and not adequate to support a decent life. Its

...overwhelmingly tokenistic features - including a neoliberal (fiscally-austere) context, the extension (not transformation) of apartheid's inheritance, and commercialisation of state services - mean the deeper crises of society and economy are not being addressed effectively by the state. (Bond, 2014: 48, emphasis added)

Hallowes (2013: 41) similarly shows that FBE 'was used to lure people into signing forms acknowledging debt to the Council. Even so, few people qualified, because 'to be indigent, you have to sit on the floor'. Interviewees remarked that, 'If you have a kettle or a TV or a stove or even a chair, you are not indigent' (Hallowes, 2013). Therefore, if someone is disconnected '...we have the snakes organise for us'. This use of 'snakes' is a subversion of an Eskom advertisement which 
tries to brand people who do illegal connections as anti-social'. The indigent list approach has been roundly criticized by progressive analysts. 'Targeting' requires effort to identify non-genuine recipients in ways that deeply affect welfare as perceived by the public (Walker, 1993: 146-147). Nevertheless, 'even a sophisticated state would be hard pressed to devise and administer a means test which can finely discriminate income and asset levels in households' (Lund, 2009: 280). The deserving and undeserving distinction is paralleled in South Africa by the 'can and can't pays'. Means tests are open to corruption, and programmes are beset by problems of low uptake. Wilson and Pereira similarly noted that indigency remains a zone of uncertainty for residents rather than outright patronage.

In many poor areas in Cape Town, households receive very high municipal bills which they are unable to pay. This is due to a number of issues, including leaks, inherited debt from previous owners, and many outside people using a household's water. Most residents don't know about their water rights and the indigent policy of the City of Cape Town. Some are aware that they receive a free basic amount of water but do not understand the complicated rebate system and what it implies for them. Residents are afraid to go and negotiate with the City to arrange for settling their debt, because several residents have found that when they go forward, they are then told that they must pay immediately, or receive disconnection of supply letters. (Wilson and Pereira, 2012)

As Titmuss (Abel-Smith, 1987: 131) observed, social programmes can often be a palliative for the diswelfares of capitalism whose fundamental role is to 'induce a sense of inferiority among those using a public service'. Indigent programmes might do little to alter the structural situation of the poor - making any simple claim that they are pro-poor doubtful - but they do affect the state's reach over the poor. On the other hand, concessions - even if limited - do make a difference in survival and building resistance movements (Latakgomo, 2011) and there is a need to investigate them further for their oscillations, ambiguities and political effects. There is, of course the problem, identified by Fraser (2012), that the leftist critique of neoliberalism and top-down bureaucratic welfare can be assimilated into a right-wing anti-statist viewpoint.

\section{Concluding remarks}

I have explored the convoluted micro-administrative politics of assisting and governing the poor in municipalities in South Africa. Municipal social packages for the registered poor offer real concessions and are not mere tokenism. However, municipal assistance programmes have created an intricate local surveillance and credit control system in which the poor's access to municipal services is regulated by the local state. The moving boundary between helping and controlling the poor in South Africa has created new black subjects of local administration. Policy makers invariably have underlying ideas about recipients' needs and predispositions. What also emerges from this study is a basic 'tension' in social welfare between the state's caring role and bureaucratic social control. Efforts to help the poor may be entangled, if not compromised, by efforts to control claimants, their attitudes and behaviour. The state also imposes concepts of needs and 'resources', creating struggles with communities about what these are and whose standards of needs and justice are being used (Harvey, 1996: 147). A stress on defining the 'needy' and weeding out unworthy or fraudulent recipients affects deeply how welfare is experienced by recipients and perceived by the public at large (Walker, 1993: 146-147).

The intensity, violence and visibility of black protest and the 'extreme and unreasonable demands' of the poor speak to new confidence among the black masses but this has become a nightmare for the local state, capital and fearful urban elites. ${ }^{5}$ The poor have taken matters into 
their own hands through popular illegalities such as land 'invasions', 'stealing' electricity, infrastructure, damaging municipal property, 'stealing' water and in some cases meting out collective punishment through people's justice. As the list of those categorized as poor grows longer and social crisis deepens, indigency and free services will become an even larger area of class conflict between the local state and the poor.

Despite numerous policy pronouncements about being pro-poor and committed to social cohesion, the victims of apartheid in black townships and yesterday's anti-apartheid heroes have become today's anti-public villains, subject to harsh policing while service delivery is increasingly designed to control recipients' behaviours, criminalise and 'exit' them rather than empower citizens (Ruiters 2011; Naidoo, 2006, 2010). In perhaps the most unequal country, with powerful economic elites still mainly white, all manner of positive reinforcements are accorded to 'loyal ratepayers', investors who get 'red carpet' treatment. Top ANC leaders and municipal bureaucrats have embraced the conservative anti-welfare stance while recognising the plight of the poor (see various policy statements on municipal indigent policies by Zuma and municipal leaders). The poor form a vast electoral support base for the ANC - a fact that surely cannot be ignored. The ANC appears as both ally and enemy of the poor. The poor, meanwhile, are active using weapons of the weak, tacitly approved transgressions and popular illegalities, to shift the moving boundary of control and concessions.

There are lessons for all municipalities seeking a more sustainable and democratic path to citizenship as opposed to an ongoing low-level war with poor citizens. There is scope to broaden and deepen notions of citizenship to incorporate issues such as the right to place, rights to the city, to land, indigenous values and practices, livelihoods, and access to resources such as water; and issues beyond national states, to include global regulation. Change needs to be about both the content and forms urban citizenship and governance. Democratically derived notions of ecologically sensitive, social needs for decommodified municipal services need to be linked with new forms of community.

\section{Funding}

The author(s) received no financial support for the research, authorship, and/or publication of this article.

\section{Notes}

1. Face-to-face interviews were conducted by the author in two municipalities in different provinces (Gauteng and the Free State province). Key informants were senior municipal officials and local social movement leaders. The sites were chosen because of major protests that had occurred with regard to indigent lists and service delivery. These municipalities were non-metro municipalities.

2. http://www.midvaal.gov.za/files/budgets/2014-2015/Indigent\%20Policy.pdf).

3. www.ipsnews.net/.../politics-south-africa-39one.

4. www.sowetanlive.co.za/news/2012/04/19/izinyoka-nyoka-is-a-way-oflife)

5. See Ruiters (2014) for an account of the National Union of Metalworkers of South Africa's breakaway from the African National Congress and the Marikana strikes, and see Neocosmos (2016).

\section{References}

Abel-Smith B (ed.) (1987) The Philosophy of Welfare: Selected Writings of Richard M Titmuss. London: Allen and Unwin.

Arntz T, Bekker K and Botes L (2003) Strategies for indigent policy formulation and implementation in urban settlements in South Africa. Journal of Public Administration 38(2): 102-117.

Atkinson D (2002) A passion to govern: Third generation issues facing local government in South Africa. Pretoria: Human Sciences Research Council. 
Berman J (2016) The politics - and economics - of patronage. Politicsweb 29 February. Available at: http://politicsweb.co.za/news-and-analysis/the-politics-and-economics-of-patronage (accessed 24 August 2016).

Bond P (2008) Social movements and corporate social responsibility in South Africa. Development and Change 39(6): 1037-1052.

Bond P (2014) Tokenism in South African social policy. Transformation: Critical Perspectives on Southern Africa 86(1): 48-77.

Business Day (2011) Lifestyle audits for ordinary citizens too'. Available at: http://www.bdlive.co.za/ articles/2011/09/08/lifestyle-audits-for-ordinary-citizens-too (accessed 3 September 2015)

Clarke J (2004) Dissolving the public realm? The logics and limits of neo-liberalism. Journal of social policy, 33(1): 27-48.

Clarke J and Newman J (1997) The Managerial State. London: Sage.

City of Cape Town (2014) Integrated Annual Report 2013/2014. Available at: https://www.capetown.gov.za/ en/Reports/Documents/ (accessed 24 September 2015)

Connolly W (2008) Capitalism and Christianity American Style. Duke University Press.

Cosatu (2006) General Secretariat Report to 2006 Congress. Available at: www.cosatu.org.za/show. php?ID=2150 (accessed 05 April 2015).

Dawson HJ (2014) Patronage from below: Political unrest in an informal settlement in South Africa. African Affairs 113(453): 518-539.

Department of Finance (2001) Intergovernmental Fiscal Review, Pretoria.

Devereux S (2011) Social protection in South Africa: exceptional or exceptionalism? Canadian Journal of Development Studies/Revue Canadienne d'Études du Développement 32(4): 414-425.

Dlamini A (2011) Restructuring intergovernmental transfers: The case of Mogale. Master's Thesis, University of Witwatersrand, South Africa.

DWA (2004) A history of the first decade of Water Service delivery. Available at: https://www.dwa.gov.za/ documents/publications/firstdecade.pdf (accessed 23 August 2011).

Ekurhuleni Municipality (2014) Indigent Support Policy. Available at: http://www.ekurhuleni.gov.za/601indigent-support-policy-125/file (accessed 19 August 2015).

Fraser N (2012) Feminism, capitalism, and the cunning of history: An introduction. Foundation Maison Des Sciences de L'Homme Working Paper 17: 1-14.

Hallowes D (2013) Talking Energy - groundWork 49. Available at: http://www.groundwork.org.za/reports/ FINAL\%20Talking\%20Energy (accessed 29 September 2015).

Harvey D (1996) Justice, Nature and the Geography of Difference. Oxford: Blackwell.

Hemson D, Dube B, Mbele T, Nnadozie R and Ngcobo D (2006) Still paying the price: Revisiting the cholera epidemic of 2000-01 in South Africa. Municipal Services Project Occasional Papers Series (8). Grahamstown: Grocott's Publishers.

Independent Online (2012) 'Ratanda burns', Available at: http://www.iol.co.za/the-star/ratanda-burns-aselectricity-protest-grows-1260896 (accessed 29 September 2015).

Independent Online (2015) 'Stop waiting for handouts', 25 March 2015. Available at: http://www.iol.co.za/ news/politics/stop-waiting-for-handouts--zuma-1836753 (accessed 29 June 2015).

Independent Online (2015) 'Municipal indigent register clean up', 11 June 2015. Available at: http://www. iol.co.za/news/politics/municipal-indigent-register-clean-up-1870569 (accessed 10 July 2015).

Kasrils R (2000) Media statement by Minister of Water Affairs and Forestry, 13 October 2000. Available at: http://www.DWAF.gov.za/Communications/PressReleases/2000/Free\%20Water.pdf (accessed 19 January 2015).

Latakgomo CN (2011) The experience and views of indigent older persons in Atteridgeville on the indigency policy/programme of local government. Master's Thesis, Pretoria University, South Africa.

Lesedi Local Municipality (2015) Available at: www.lesedilm.gov.za/.../LLM\%20Indigent\%20Policy\%20 2015-2016.pdf (accessed 30 August 2015).

Lund F (2009) South Africa: transition under pressure. International social policy: In: Alcock P and Craig G (eds) Welfare regimes in the developed world, (second edition) London: Palgrave. 
Makhubu N (2013) Open debate: Ephemeral democracies - interrogating commonality in South Africa. Third Text 27(3): 415-418.

Mbeki T (2004) State of the Nation Address. Available at: http://www.iol.co.za/.../text-of-mbekis-state-ofthe-nation-speech-233758 (accessed 12 September 2015).

Mbombela Local Municipality (ND) Indigent Policy. Available at: http://www.mbombela.gov.za/indigent\%20 policy.pdf (accessed 5 July 2015).

McDonald D (2002) The bell tolls for thee. In: McDonald D and Pape J (eds) Cost Recovery and the Crisis of Service Delivery. Pretoria: HSRC Press.

McDonald D and Ruiters G (2005) The Age of Commodity: Water Privatization in Southern Africa. London: Earthscan.

Mead L (1993) The New Politics of Poverty: The Nonworking Poor in America. New York: Basic Books.

Midvaal Municipality (2014) Indigent Policy. Available at: www.midvaal.gov.za/files/budgets/2014-2015/ IndigentPolicy.pdf (accessed 5 July 2015).

Muller M (2001a) Free basic water challenge. Water Sewage and Effluent 21(4): 14-16.

Muller M (2001b) Speech by Director General at International Freshwater Conference, Bonn, Germany, 03 December 2001. Available at: www.dwa.gov.za/.../Speech\%20by\%20Director-General $\% 20$ at $\% 2$ (accessed 12 June 2015).

Naidoo P (2006) Indigency: An attack on 'the poor/s'. University of KwaZulu-Natal, Centre for Civil Society, Available at: http://ccs.ukzn.ac.za/files/Naidoo\%20indigency.pdf (accessed 4 January 2016).

Naidoo P (2010) Indigent management: A strategic response to the struggles of the poor in post-apartheid South Africa.Development or Decline 156-159.

Neocosmos M (2016) The Marikana moment, worker political subjectivity and state violence in postapartheid South Africa. Journal of Asian and African Studies 51(2): 135-142.

New York Times (2003) 'Water Tap often shut for the poor', 29 May 2003.

Palmer Development Group (2001) Free Basic Water, Tshwane: A case study prepared for DWAF. Available at: http://www.DWAF.gov.za.freebasicwater.docs.casestudies (accessed 3 October 2006).

Pillay U (2010) Exit strategy for indigents, City of Tshwane. Available at: www.hsrc.ac.za/en/researchoutputs/ktree-doc/4472 (accessed 20 July 2014).

Pithouse R (2008) A politics of the poor shack dwellers' struggles in Durban. Journal of Asian and African Studies 43(1): 63-94.

Pointer R (2015) From illegitimate disruption to failing state: How South African newspapers framed 'service delivery' protests in 2013. Master's dissertation, University of Cape Town, South Africa.

RSA (2005) DPLG Draft Indigence Framework, September 2005. Available at: http://fbs.dplg.gov.za/fbs/ site/docs/DocumentLibrary/IP/Guidelines.pdf?PHPSESSID=dd245e1 e43caadb037d2946bfb74cd74 (accessed 2 October 2015).

RSA (2006) Guidelines for the implementation of Municipal Indigent Policies. Pretoria. Available at: https://www.westerncape.gov.za/text/2012/11/national_framework_for_municipal_indigent_policies. pdf (accessed 23 August 2015).

RSA (2013) Non-Financial Census of Municipalities. Available at: http://www.statssa.gov.za/publications/ P9115/P9115June2013.pdf (accessed 12 October 2015)

RSA (2014) Poverty Trends Report. Pretoria: Statistics South Africa.

RSA (2015) Non-financial Census of Municipalities: Statistical Release P9115. Pretoria: Statistics South Africa.

Ruiters G (2007) Contradictions in municipal services in contemporary South Africa: Disciplinary commodification and self-disconnections. Critical Social Policy 27(4): 487-508.

Ruiters G (2011) The Fate of the Eastern Cape. Pietermaritzburg: UKZN Press.

Ruiters G (2014) Spaces of hope: Rethinking trade union-community alliances and citizenship in a postalliance era in South Africa. Politikon 41(3): 421-441.

SA News (2009) Indigent households. Available at: http://www.sanews.gov.za/south-africa/indigent-households-must-submit-documents-access-services (accessed 22 August 2014).

Seri (2013) Targeting the poor: Free basic services and Municipal Indigent Policies. Available at: http://www. seri-sa.org/images/Targeting_the_Poor_Nov13.pdf (accessed 2 September 2016) 
Sowetan (2015) 'Culture of Non-Payment' is costing Gauteng billions, 14 March 2015.

Szabó A (2015) The value of free water: Analyzing South Africa's Free Basic Water policy. Econometrica 83(5): 1913-1961.

The Economist (2003) Survey of Water, 19 July 2003.

Times Live (2015) Money for dstv. Available at: http://www.timeslive.co.za/thetimes/2015/05/20/Moneyfor-DStv-but-none-for-municipal-services (accessed 4 October 2015).

Tissington K (2008) Water services fault lines: An assessment of South Africa's water and sanitation provision across 15 municipalities. Johannesburg: Centre for Applied Legal Studies.

Walker C (1993) Managing Poverty: The Limits of Social Assistance. London: Routledge.

Weiss C (1998) Evaluation, (Second Edition). Upper Saddle River, NJ: Prentice Hall.

Wilson J and Pereira T (2012) Water demand management's shadow side: Tackling inequality and scarcity of water provision in Cape Town. Report 7, EMG Water and Climate Change Research Series.Cape Town.

Wright G, Noble M, Ntshongwana P, Neves D and Barnes H (2014) Lone Mothers: Social security and the dignity of lone mothers in South Africa. Working Paper 3, Cape Town: Plaas.

\section{Author biography}

Greg Ruiters is the former Mathew Goniwe Chair in Development and Society at Rhodes University, South Africa. He is currently professor of Public Policy at the School of Government, University of Western Cape. His recent books include 'The Fate of the Eastern Cape: History, Politics and Social Policy' and 'Universal Health Care in Southern Africa' (with Robert Van Niekerk). 